\title{
REFLECTIVE PRACTICES OF SECONDARY SCHOOL TEACHERS AND CLASSROOM MANAGEMENT \\ ${ }^{1}$ Dr. Muhammad Zafar Iqbal
}

\begin{abstract}
Classroom management is identified with classroom discipline, paying individual attention to students, adoption of suitable teaching method, use of teaching instruments e.g. selection of audio visual aids and designing interesting activities for students. This paper examines the practices of secondary school teachers to reflect over their classroom management skills. The population of the study comprised of secondary school teachers teaching in the public secondary schools of Rawalpindi. 295 male and female teachers were taken as sample. Data were collected through questionnaire. Descriptive analysis was made to see the tendencies and then variables were computed to run linear regression analysis. Results of the study show that reflection of teachers on their classroom management can improve their classroom management skills. There is a dire need to highlight the importance of reflective practices among secondary school teachers to stop them to rely on traditional methods of teaching.
\end{abstract}

Keywords: Reflection, Classroom Management, Reflective Practices, Teachers, Professional Development

\section{Introduction}

Teaching is a complex activity; many aspects are mysterious about it. Since 1987, reflective practices are widely discussed term in the field of teacher education (Kourieos, 2012). Various terms e.g. "reflection" "reflective practice" "reflective teaching" or "reflective practitioner" are often used. Teachers are encouraged to become reflective practitioners to implement their professional knowledge in a realistic way (Bentham, 2004; Tedick, 2005). Teachers are essentially required to learn and demonstrate emerging reflective teaching learning skills for their own professional identity (Levey \& Robets, 2005). Day by day the notion of reflective practices is getting popular. Teachers are expected to reflect

1 Assistant Professor, Department of Education, International Islamic University Islamabad: Email m.zafar@iiu.edu.pk 
upon their actions through a variety of ways to improve their classroom management skills and to make their teaching more effective. Reflective practices make it easier for teachers to learn from their own experience and apply newly acquired skills to manage their classes. Acknowledgment of own strengths, weaknesses and skills is starting point to initiate reflection. Teachers are expected to set classroom management norms and rules and display such rules for their students. Reflective teachers inform their students that what is expected from them in the classroom. Classroom norms can vary from class to class and teacher to teacher depending upon the culture. Usually reflective teachers display classroom management norms for their students on the display board e.g. starting time, what about latecomers, respect for others point of view, how students can avoid disrespect and self-monitoring rules. Similarly daily routines, tasks and activities that have to be carried out every day e.g. cleaning of the classroom, switching on/off electronic devices, opening and closing windows, collecting and passing out textbooks, notes or other materials should be displayed in the classroom (Plessis, 2002). Effective teachers always display classroom management rules in their classrooms (Kourieos, 2012).

\subsection{Objectives of the Study}

This study was carried out to achieve the following objectives:

1. To study the teaching practices of secondary school teachers to reflect over their actions to manage their classes.

2. To study the effects of reflective practices on classroom management skills of secondary school teachers.

\subsection{Research Questions}

This study was guided by the following research questions:

1. Do student teachers reflect over their actions to manage their classes during teaching?

2. To what extent reflective practices contributes to improve the classroom management skills of secondary school teachers?

\section{Literature Review}

Professional Learning through reflections is a peaceful and lengthy process, which involved active self-evaluation and evaluation of professional practices. Teachers can learn required teaching skills through 
self-reflection. Reflective practice is a powerful learning strategy, but it demands self-questioning (Greenwood, 1998). Stewart, (2002) says that reflective approach of professional learning fulfills following functions:-

$>$ Reflective learning approach allows professionals to analyze their own experience and facilitates them to learn from experience.

$>$ This approach promotes critical thinking, questioning attitude and leads professionals towards greater autonomy.

$>$ This approach encourages professionals to build competencies by recognizing their weaknesses.

$>$ This approach provides written proof of the learner's progression in thinking, deeper their understanding and enables them to apply new knowledge.

$>$ At higher education level, this approach enables teachers to promote their relationships with students and colleagues (Stewart, 2002).

According to Mcintyre \& Byrd, (2000) ability of teachers to rethink their teaching experience to analyze the complexity of the embedded actions is called reflection on action. Teachers can make a fair analysis of their teaching experiences by reflecting on their actions (Mcintyre \& Byrd, 2000). Professional leaning through reflective practices depends upon learning agenda of teachers (Raelin, 2002). Teachers may involve senior teachers to explore their experience or to address several issues relating to their teaching practices (Jasper, 2003). As compared to novice teachers, experienced teachers can travel around all the features of their experience alone in a better way. Personal reflection is powerful way to view the experience from a new frame of reference. Exploration of experiences leads teachers to develop new teaching theories (Sotto, 2004). Woolfok, (2004) says that trainee teachers need to reflect over following points whenever they plan a lesson:

How to maintain the class room discipline?

How to motivate the students?

How to deal with individual differences of students?

How to evaluate and assess the students work? and

How to deal with parents? (Woolfok, 2004). 
Involvement in reflective practices demands from teachers to actively examine their thoughts and feelings. Teachers can focus on their feelings about the event, instead of merely focusing on the outcomes during teaching learning process. Teachers may initiate reflective practices through structured observations, professional portfolios and by taking well thought-out feedback. Professional learning through reflective programmes may also be launched for the professional development of teachers. Success of all the professional development programmes depends upon the practice of newly acquired skills in practical classroom settings. Reflective teachers know better that to what extent they are applying the research based theories in real class situations.

To a large extent classroom management skills of trainee teachers are influenced by the working conditions and cultural settings at the cooperating school. Classroom management mastery includes learning and gaining command over new duties and roles as a teacher and developing self-confidence to reach the required level of performance (Feldman, 1981). Numerous researches in the field of classroom management issues and socialization of new teachers (Moon, 2005; Osterman \& Kottkamp, 2004; Bound, 2011; Bughio, 2013) have identified a relationship between reflective practices of teachers and their professional development. Several factors are directly related with the classroom management e.g. physical conditions, classroom settings, size of class, number of students, quality and availability of resources and time duration. In Pakistani institutions little attention is paid to provide mentoring and supervision services to teachers. Likewise, classroom settings and day to day training to deal with classroom management problems are not focused areas in faculty development projects. Rather traditional teacher training programmes, comprising absolute training workshops have been emphasized (Tahir \& Qadir, 2012). Learning how to teach and working to become an excellent teachers is a lengthy process that requires not only the development of very practical and complex skills under the guidance and supervision of experts, but also the acquisition of specific knowledge and the promotion of certain ethical values and attitudes. Teachers should be competent in knowing what to teach, how to teach, when to teach and why they are teaching (Reimers, 2003). 


\section{Research Methodology}

Study was descriptive in nature. The population of the study comprised of secondary school teachers teaching in public secondary schools of Rawalpindi. Convenient sampling technique was used to select the sample, $150(50.8 \%)$ male and $145(49.2 \%)$ female were selected through convenient sampling technique. Both male and female participants of the study were within reasonably comparable ratio. Among the respondent teachers, $42(14 \%)$ had one year teaching experience, 72 (24\%) two years, 108 (37\%) three years and 75 (25\%) four years teaching experience. Researcher personally developed a questionnaire and visited the selected school to collect the data. Collected data were analyzed by applying descriptive statistics and regression analysis.

\section{Results}

Table 1. Indicators of involvement of secondary school teachers in reflection

\begin{tabular}{|c|c|c|c|c|c|c|}
\hline$S r$. & Items & $\overline{S A}$ & $\bar{A}$ & $N$ & $D$ & $S D$ \\
\hline \multirow[t]{2}{*}{1} & I reflect over the learning objectives of my & 79 & 170 & 38 & 8 & 0 \\
\hline & lesson & $27 \%$ & $58 \%$ & $13 \%$ & $02 \%$ & 0 \\
\hline \multirow[t]{2}{*}{2} & I reflect over the management of available & 70 & 129 & 60 & 31 & 5 \\
\hline & classroom resources to use them in teaching. & $24 \%$ & $44 \%$ & $20 \%$ & $11 \%$ & $1 \%$ \\
\hline \multirow[t]{2}{*}{3} & I reflect over my confidence level during my & 73 & 150 & 40 & 30 & 2 \\
\hline & lesson & $25 \%$ & $51 \%$ & $14 \%$ & $9 \%$ & $1 \%$ \\
\hline \multirow[t]{2}{*}{4} & I reflect over the usage of teaching & 75 & 50 & 95 & 39 & 36 \\
\hline & $\begin{array}{l}\text { instruments/audio-visual aids (white board, } \\
\text { multimedia, projectors, charts) }\end{array}$ & $25 \%$ & $17 \%$ & $32 \%$ & $13 \%$ & $13 \%$ \\
\hline \multirow[t]{2}{*}{5} & I reflect over the suitability of teaching method & 92 & 145 & 55 & 4 & 0 \\
\hline & during teaching process & $31 \%$ & $49 \%$ & $19 \%$ & $0.13 \%$ & $0 \%$ \\
\hline \multirow[t]{2}{*}{6} & I reflect over different learning activities during & 90 & 128 & 45 & 32 & 0 \\
\hline & teaching process & $30 \%$ & $42 \%$ & $13 \%$ & $15 \%$ & $0 \%$ \\
\hline \multirow[t]{2}{*}{7} & I realize that my teaching method is successful & 88 & 150 & 50 & 7 & 0 \\
\hline & & $30 \%$ & $52 \%$ & $17 \%$ & $01 \%$ & $0 \%$ \\
\hline \multirow[t]{2}{*}{8} & I reflect over successful implementation of my & 100 & 140 & 41 & 14 & 0 \\
\hline & lesson plan & $35 \%$ & $49 \%$ & $15 \%$ & $01 \%$ & $0 \%$ \\
\hline \multirow[t]{2}{*}{9} & I pay individual attention to my students during & 29 & 70 & 84 & 81 & 31 \\
\hline & lesson & $10 \%$ & $24 \%$ & $28 \%$ & $27 \%$ & $11 \%$ \\
\hline \multirow[t]{2}{*}{10} & I reflect over my control on my students during & 88 & 150 & 50 & 07 & 0 \\
\hline & class & $30 \%$ & $52 \%$ & $17 \%$ & $01 \%$ & $0 \%$ \\
\hline
\end{tabular}


Table 2: Involvement of secondary school teacher in reflection and classroom management

\begin{tabular}{|c|c|c|c|c|c|c|}
\hline$S r$. & Items & $S A$ & $A$ & $N$ & $\bar{D}$ & $S D$ \\
\hline \multirow[t]{2}{*}{1} & Reflection helps me to focus on & 70 & 179 & 30 & $\overline{16}$ & 0 \\
\hline & learning objectives & $23 \%$ & $61 \%$ & $11 \%$ & $05 \%$ & 0 \\
\hline \multirow[t]{2}{*}{2} & Reflection helps me out to manage & 64 & 135 & 60 & 31 & 5 \\
\hline & available classroom resources & $21 \%$ & $45 \%$ & $20 \%$ & $12 \%$ & $2 \%$ \\
\hline \multirow[t]{2}{*}{3} & Reflection helps me out to feel & 55 & 168 & 38 & 32 & 2 \\
\hline & confident during teaching process & $19 \%$ & $57 \%$ & $13 \%$ & $10 \%$ & $1 \%$ \\
\hline \multirow[t]{2}{*}{4} & Reflection helps me out to use teaching & 61 & 74 & 100 & 34 & 26 \\
\hline & $\begin{array}{l}\text { instruments/audio-visual aids (white } \\
\text { board, multimedia, projectors, charts) }\end{array}$ & $21 \%$ & $25 \%$ & $33 \%$ & $11 \%$ & $9 \%$ \\
\hline \multirow[t]{2}{*}{5} & Reflection helps me to know the & 82 & 154 & 55 & 4 & 0 \\
\hline & $\begin{array}{l}\text { suitability of adopted teaching method } \\
\text { during teaching process }\end{array}$ & $28 \%$ & $52 \%$ & $19 \%$ & $01 \%$ & $0 \%$ \\
\hline \multirow[t]{2}{*}{6} & Taking reflection is helpful to use & 70 & 148 & 55 & 22 & 0 \\
\hline & $\begin{array}{l}\text { different learning activities during } \\
\text { teaching process }\end{array}$ & $23 \%$ & $50 \%$ & $19 \%$ & $8 \%$ & $0 \%$ \\
\hline \multirow[t]{2}{*}{7} & Reflection helps me out to realize that & 81 & 157 & 54 & 3 & 0 \\
\hline & $\begin{array}{l}\text { adopted teaching method was } \\
\text { successful }\end{array}$ & $28 \%$ & $53 \%$ & $18 \%$ & $1 \%$ & $0 \%$ \\
\hline \multirow[t]{2}{*}{8} & Reflection helps me out to successfully & 94 & 146 & 41 & 14 & 0 \\
\hline & implement lesson plan in the classroom & $32 \%$ & $49 \%$ & $14 \%$ & $5 \%$ & $0 \%$ \\
\hline \multirow[t]{2}{*}{9} & Reflection is helpful to pay individual & 35 & 64 & 81 & 84 & 31 \\
\hline & e students & $12 \%$ & $22 \%$ & $28 \%$ & $28 \%$ & $10 \%$ \\
\hline \multirow[t]{2}{*}{10} & Taking reflections is helpful to initiate & 50 & 97 & 95 & 53 & 0 \\
\hline & $\begin{array}{l}\text { disciplinary measure against students } \\
\text { of my class }\end{array}$ & $17 \%$ & $33 \%$ & $32 \%$ & $18 \%$ & $0 \%$ \\
\hline
\end{tabular}

All items were composed to apply regression analysis. Table 3 below displays results of regression model summary between reflection and classroom management.

Table 3. Model Summary of Correlation

\begin{tabular}{cccc}
\hline $\mathrm{R}$ & $\mathrm{R}^{2}$ & Adjusted $\mathrm{R}^{2}$ & $\begin{array}{c}\text { Std. Error of } \\
\text { Estimate }\end{array}$ \\
\hline .540 & .289 & .287 & .28952 \\
\hline
\end{tabular}


Predictors: (Constant), Reflection in Action, Dependent Variable: Classroom Management

The model summary shows that the correlation coefficient, is $.54\left(\mathrm{R}^{2}=\right.$ .54 ) and the adjusted $\mathrm{R}^{2}$ is .287 , that indicates that nearly $29 \%$ of the variance in classroom management can be predicted by reflection in action in classroom management skills of secondary school teachers.

Table 3. Model Summary of Correlation

\begin{tabular}{lllll}
\hline & $\begin{array}{l}\text { Sum of } \\
\text { Squares }\end{array}$ & Mean Square & F & Sig. \\
\hline Regression & 9.333 & 9.333 & 117.596 & .000 (a) \\
Residual & 25.562 & .085 & & \\
Total & 34.891 & & & \\
Predictors: (Constant), Reflection over Actions, Dependent Variable: Classroom \\
\multicolumn{2}{l}{ Management }
\end{tabular}

This table shows that the overall model is significant, $p=.000$ and that $\mathrm{F}=117.596$. This suggests that the predictor variable of reflection over action significantly predicts the criterion variable of effective classroom management.

Table 4. Correlations: Beta Coefficient

Standardized $\mathrm{t}$ Sig.

Coefficient

\section{Beta}

$\begin{array}{llll}\text { (Constant) } & & 19.193 & .000 \\ \text { Reflection over } & .527 & 10.876 & .000\end{array}$

actions

Dependent Variable: Classroom management

Coefficient table indicates the standardized beta coefficient, which is interpreted similarly to correlation coefficients or factor weights. In this table, it is shown that reflection over actions is significantly contributing to the prediction, as $p=.000$ and $\beta=.52$.

\section{Findings}

1. Eighty five percent teachers replied that they reflect over the learning objectives of their lesson, $68 \%$ responded that they reflect over available 
classroom resources and attempt to use such resources in teaching. Similarly, $76 \%$ replied that they reflect on the spot about their level of confidence during teaching.

2. Forty two percent teachers replied they reflect over the usage of teaching instruments/audio-visual aids e.g. white board, multimedia, projectors, charts etc. It indicates that majority of teachers not reflect over that they are properly using teaching instruments during teaching. But $80 \%$ teachers agreed that they reflect over that they are using suitable teaching method to teach contents and $72 \%$ agreed that they reflect over different learning activities taking place during teaching process.

3. Eighty four percent teachers agreed that they have a concern with successful completion of their lesson. Only 34\% agreed that they pay individual attention to their students during class. However, $82 \%$ replied that they attempt to control their class.

4. Eighty four percent teachers considered that taking reflection was helpful for them to focus on learning objectives, similarly $66 \%$ teachers agreed or strongly agreed that taking reflection is helpful to manage available classroom resources. A vast majority $76 \%$ teachers considered that taking reflection may helpful for them to develop confidence during teaching process.

5. Only $46 \%$ teachers replied that taking reflections help them out to use teaching instruments/audio-visual aids e.g. white board, multimedia, projectors, charts etc. 33\% respondents remained neutral and 20\% disagreed that taking reflection is helpful to use teaching instruments/audio-visual aids e.g. white board, multimedia, projectors, charts etc. Almost $80 \%$ respondents were of the view that reflection helps them out to adopt suitable teaching method during teaching process and to use different learning activities during teaching process. Similarly, they replied that taking reflection facilitate them to realize that adopted teaching method was suitable to teach the selected contents.

6. Eighty one percent teachers thought that reflection is helpful to implement lesson plan successfully, but only 34\% teachers replied that involvement in reflection enable teachers to pay individual attention to their students. It indicates that majority of teachers considered that 
involvement in reflection is not helpful for teachers to pay individual attention to their students. In the same way only $40 \%$ teachers replied that taking reflections is helpful to initiate disciplinary measure against their students.

7. Regression summary (value of $\mathrm{R}^{2}=.287$ ) shows that almost $29 \%$ of the variance in classroom management can be predicted by the involvement of teachers in reflection to manage their class.

\section{Conclusions}

1. A majority of secondary school teachers reflected over the learning objectives of the lesson, they taught to their students. Similarly, they reflected over available classroom resources and attempted to use available resources in the teaching process. Likewise they reflected over their level of confidence during the process of teaching.

2. Majority of secondary school teachers were not aware about the benefits of proper usage of Audio Visual Aids. Majority of secondary school teachers did not reflect over the suitability of adopted teaching method with the contents of the lesson. Teachers did not reflect over activity based teaching to involve their students in different classroom learning activities. Majority of teachers did not pay full attention to invite the individual attention to their students during the teaching process.

3. A majority of teachers did not pay full attention to control their classes by assigning learning activities. However, they were of the view that taking reflection may help them out to remain focused on students learning objectives. They were of the view that taking reflection may help them out manage available classroom resources and to remain confident during the teaching process.

4. Majority of teachers agreed that taking reflection was helpful for them to adopt suitable teaching method and to plan different learning activities during teaching process. Similarly, they replied that talking reflection facilitate them to realize after the class that adopted teaching method was suitable to teach the selected contents.

5. A majority of secondary school teachers considered that taking reflections may helpful them to implement the lesson plan successfully and deal with discourteous attitude of their students to initiate disciplinary measures against such students. 


\section{Discussion}

Results of many studies revealed that there is a relationship between reflective practices, dealing with classroom management related issues and socialization of novice teachers (Moon, 2005; Osterman \& Kottkamp, 2004; Bound, 2011; \& Bughio, 2013). Teacher's involvement in reflection and consideration of beliefs, knowledge and thoughts regarding classroom can be done by teachers themselves for various purposes (Brown 2000). Teachers may examine their professional beliefs and practices regarding classroom management through students' feedback, observation, reflective questioning and critical reflections. This paper expose that there is a relationship between reflections of teachers over classroom management practices. Results of the study by (Spiri, 2011) show that process of cultivating self-awareness and determining motives for classroom policies is particularly valuable for those teachers seeking to defuse or avoid volatile or merely disruptive situations in the classroom. Self-reflections lead teachers towards patterned responses in any given classroom situation (Pratt, 2002). Teaching is complex task and teachers need to reflect upon what they have done in the class. This process can be enhanced when they receive informed criticism concerning their work from their colleagues. Reflective practice is likely a formula for effective teaching (Eisner, 2002). Results of present study show that involvement in reflective practices can develop a deeper understanding about own teaching style and suitability of adopted teaching method. A study conducted by Ferraro (2000) and Amoh (2011) reflects that ability of teachers to question and understand their own actions significantly contributed for professional development of teachers. Similarly the results of study in hand shows that involvement of teachers in reflective practices make it easy for teachers to focus on leaning objectives, effectively use available classroom resources, management of class, design various activities for students and successfully implement lesson plan in the class.

\section{Recommendations}

1. Taking reflections is an art and professional activity. Although reflection can play a substantial role in the professional development of teachers, yet they usually avoid reflecting on their actions. Teachers may initiate reflective practices to make their teaching more effective. 
2. Teachers may reflect over the learning objectives of the lesson, available classroom resources and individual differences of their students. It will facilitate them to achieve learning objectives, to use available classroom resources, and cater individual differences of learners. Similarly, teachers may reflect over their level of confidence to keep them confident during the process of teaching.

3. Teachers are required to reflect over the suitability of teaching method and how they can involve their students in different classroom learning activities. Teachers may reflect to deal with discourteous attitude demonstrated by their students during the process of teaching and initiate proper disciplinary actions against such students.

\section{References}

Amoh, S. A. (2011). The Reflective and Collaborative Practices of Teachers in Ghanaian Basic Schools: A Case Study (Doctoral dissertation). $\quad$ Retrieved from http;/ethese.nottingham.ac.uk/2012/1/1.thesis-final.pdf.

Bentham, S. (2004). A Teaching Assistants' Guide to Child Development and Psychology in the Classroom. London: Routledge flamer

Bound, H. (2011). Reflective Practitioner and Professional Learning in CET. IAL, Singapore. Retrieved from: http;//www.ial.edu.sg/files/documents/426\%20CET.pdf.

Brown, B. (2003). Teaching style vs. Learning style. Retrieved Sept. 14, 2010,from http://www.scribd.com/doc/6706642/LearngStyleVSTeach gStyle

Bughio, F. A. (March, 2013). Issues and Challenges in Doing Action research in a public sector university. Paper presented at NUML, International conference on quality of higher education

Eisner, E.W. (2002). The Arts and the Creation of Mind. Connecticut: Yale University Press. 
Feldman, D. (1981). The Multiple Socialization of Organization Members. The Academy of Management Review, 6(2), 309. http://dx.doi.org/10.2307/257888

Ferraro, J. M. (2000). Reflective Practice and Professional Development. Washington DC: ERIC Clearinghouse on Teaching and Teacher.

Greenwood, J. (1998). The role of reflection in single and double loop learning. Journal of Advanced Nursing, 27(5), 1048-1053. http://dx.doi.org/10.1046/j.1365-2648.1998.00579.x

Jasper, M. (2003). Beginning Reflective Practice. UK: Nelson Thomes.

Kourieos, S. (2012). The Impact of Mentoring on Primary Language Teacher Development During The Practicum. Winter (15), 57-64. http://www.elted.net/issues/volume-15/7.\%20Stella\%2013.pdf

Levey, P., \& Roberts, S. (2005). Developing the New Environment: The Changing Role of Academic Librarian. U.K: Facet publishing.

Mcintyre, D. J., \& Byrd, M. D. (2000). Strategies for Career Long Teacher Education Teacher Education Year Book (VI). California: Crown Press.

Moon, J. A. (2005). Reflection in Learning \& Professional Development: Theory and Practice. UK: Kogan Page.

Osterman, K. E., \& Kottkamp, R. B. (2004). Reflective Practice for Educators: Professional Development to Improve Student Learning (2nd ed.). Newbury Park, CA: Corwin Press.

Plessis, D. J. (2002). In my Classroom A Guide to Reflective Practice. Washington DC: American Institutes for Research. 
Pratt, D. (2002). Good Teaching: One Size Fits All? Retrieved Sept 14, 2010from http://www.fsu.edu / elps/ ae/download /ade5080/Pratt.pdf.

Raelin, J. (2002). "I Don't Have Time to Think!" versus the Art of Reflective Practice. Reflections: The Sol Journal, 4(1), 66-79. http://dx.doi.org/10.1162/152417302320467571.

Reimers, V.E. (2003). Teaches Professional Development: An International Review of Literature. Paris: UNESCO, International institute of Educational Planning.

Sotto, E. (2004). When Teaching Become Learning A Theory of Practice of Teaching. London: Continuum.

Spiri, J. (2011). Classroom Management and Discipline Policies: Reflect and Formulate. Retrieved from: http://blog.nus.edu.sg/eltwo/2011/03/18/classroom-management-anddiscipline-policies-reflect-and-formulate/ on 04.07.2014

Stewart, M. (2002). Approaches to Learning Reflective Practice. UK: JMU Teaching \& Learning Press

Tahir, A. \& Qadir, S.A (2012). Challenges of Classroom Management to Effective Teacher Socialization: A Study of Beginning English Teachers. Pakistan Journal of Social Sciences, 32(1), 21-37.

Tedick, D. (2005). Second Language Teacher Education International Perspectives (Ed.). Mahwah NJ: Erlbaum.

Woolfok, A. (2004). Educational Psychology. New York: Pearson. 